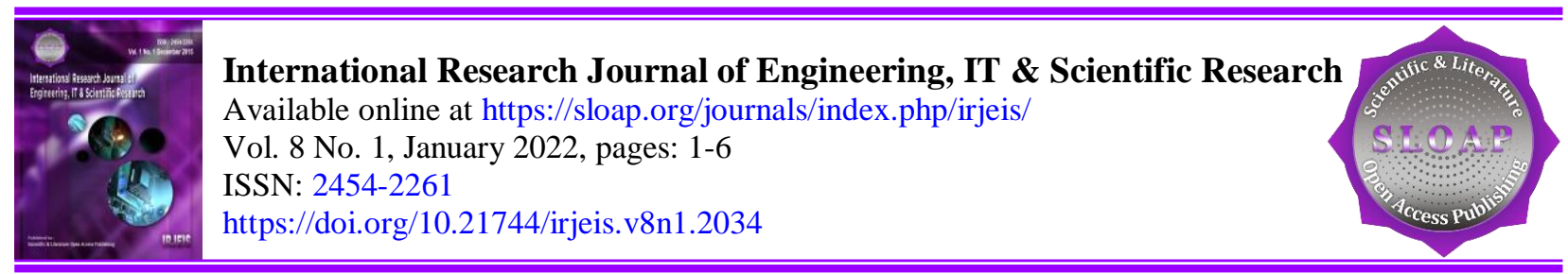

\title{
Evaluation of the Implementation of Occupational Safety and Health Management Systems on the Ayana Nort Wing Bali Construction Project
}

\author{
I Ketut Sutapa a \\ Ni Kadek Sri Ebtha Yuni ${ }^{b}$ \\ I Nengah Darma Susila ${ }^{c}$ \\ I Gede Sastra Wibawa ${ }^{d}$ \\ I Made Anom Santiana ${ }^{\mathrm{e}}$
}

\section{Article history:}

Submitted: 27 November 2021

Revised: 18 December 2021

Accepted: 05 January 2022

\section{Keywords:}

geotextile;

occupational safety;

slope sliding;

slope stability;

SMK3;

\begin{abstract}
Building construction projects have a high level of risk of work accidents, especially for workers in the field. Therefore, at the time of implementation of construction work, it is necessary to evaluate the implementation of occupational safety and health management system (SMK3) to provide a sense of security to workers in the field of this research aimed at evaluating SMK3. This research uses qualitative and quantitative methods to know the implementation of SMK3, by taking data by conducting structured interviews conducted on the building construction project Ayana Nort Wing Bali. Analysis conducted a descriptive analysis based on Government Regulation of the Republic of Indonesia No.50, 2012 advanced with 12 criteria containing 166 criteria elements. The result of this study is the application of PP No. 50 of 2012 for the advanced level of $92.89 \%$ categorized as satisfactory. In addition, there are 14 that have not been implemented. This the company that the evaluation level of occupational safety and health management system (SMK3) in the building construction project Ayana North Wing Bali is the level of application is very satisfactory for the project.
\end{abstract}

International research journal of engineering, IT \& scientific research (C) 2022. This is an open access article under the CC BY-NC-ND license (https://creativecommons.org/licenses/by-nc-nd/4.0/).

Corresponding author:

I Ketut Sutapa,

Department of Civil Engineering, Bali State Polytechnic, Indonesia.

Email address: ketutsutapa@pnb.ac.id

${ }^{a}$ Department of Civil Engineering, Bali State Polytechnic, Indonesia

${ }^{b}$ Department of Civil Engineering, Bali State Polytechnic, Indonesia

${ }^{c}$ Department of Machine Engineering, Bali State Polytechnic, Indonesia

${ }^{d}$ Department of Civil Engineering, Bali State Polytechnic, Indonesia

e Department of Civil Engineering, Bali State Polytechnic, Indonesia 


\section{Introduction}

Along with the rapid development of building construction in Indonesia, the role in controlling the perceived risk of work accidents becomes increasingly important. Construction workers are workers who quite a lot use a variety of sophisticated and manual equipment. The use of equipment that is limited in breadth with various types of activities carried out is very risky and high in terms of accidents. In addition to equipment, the lack of knowledge of workers in Occupational Safety and Health (K3) and also in K3 supervision is one of the factors in the occurrence of work accidents (Santoso, 2004).

Human resources also play an important role in the success of an organization or company. Because humans are living assets that need special attention by companies. The fact that humans are the main asset in an organization or company, must get serious attention and be managed as well as possible (Xie et al., 2020; Tao et al., 2020). This is intended so that the human resources owned by the company can provide optimal contributions in the effort to achieve organizational goals (Apsari \& Purnomo, 2020). In human resource management, there is also one thing that must be a concern, namely, the Occupational Health and Safety Management System (Leyn, 2019). Occupational Health and Safety (K3) is a concern for human welfare, currently, industrialization is a process of socio-economic change that changes the industrial system to a wider scale and the provision of services develops faster (Zambrano et al., 2021). Health problems in the workplace, occupational safety, and health hazards are currently considered as the driving force and looking for solutions on how to prevent the negative impact of the construction industry on employees (Sholihah, 2018).

The ILO (International Labor Organization) is the global body responsible for developing and overseeing international labor standards. In collaboration with its 181 member countries, the ILO seeks to ensure that these labor standards are respected both in principle and in practice (Noorzad \& Mirmoradi, 2010; Bergado et al., 2002). According to ILO estimates, every year around the world 2 million people die from work-related problems. Of this number, 354,000 people had fatal accidents. In addition, every year there are 270 million workers who experience work-related accidents and 160 million are affected by work-related diseases (Herdiansyah, 2015). The number of occupational safety and health (K3) in construction in Indonesia, in general, is still low. Based on ILO data, Indonesia is ranked 26th out of 27 countries (Leyn, 2019).

Based on the number of work accidents and the lack of implementation of SMK3 on projects in Indonesia, especially in the province of Bali (Darwis et al., 2021; Endroyo et al., 2015). Because Bali is famous for its natural and cultural beauty, many tourists visit to enjoy holidays to the island of Bali and stay at hotels in Bali and do not except for the Ayana Wings Bali hotel, which was built for the convenience of local and foreign tourists visiting Bali (Fernández-Muñiz et al., 2009; Sousa et al., 2014). So before this project is built, the company will make risk control on the project and provide work comfort and most important occupational health when working on the project so that the project runs smoothly and follows the specified timeframe and does not cause work accidents, then the project is carried out the implementation of occupational safety and health management system (SMK3) and has been regulated according to PP NO. 50 of 2012 because the PP regulation NO. 50 of 2012 contains risk control and activities where workers in the project are safe, efficient, and productive and to prevent work accidents and occupational diseases safety and security at the dam will also be evaluated for the implementation of the Occupational Health and Safety Management System (SMK3) in the building construction project at Ayana North Wing Bali (Malkawi et al., 2000; Lee et al., 1995). Based on the description above, this research refers to the application of SMK3 for occupational safety and health, and Evaluation of the Application of Occupational Health and Safety Management System (SMK3) will be carried out which refers to PP NO. 50 of 2012 at the location of the Building Construction Project in Ayana North Wing Bali. To review the safety and health of the project work. Based on the description above, the formulation of the problem in this study is as follows:

1) What are the assessment criteria for the Occupational Safety and Health Management System (SMK3) in building construction at Ayana North Wing Bali?

2) What is the level of implementation of the Occupational Health and Safety Management System (SMK3) on the building project at Ayana North Wing Bali?

In this research, there are several objectives to be achieved, including: 
1) Know the assessment criteria for the Occupational Health and Safety Management System (SMK3) for the building project at Ayana North Wing Bali.

2) Knowing the level of implementation of the Occupational Health and Safety Management System (SMK3) on building projects at Ayana North Wing Bali.

With this research, benefits can be obtained, among others:

1) For companies, this research is expected to provide input in developing an occupational safety and health system at the Ayana North Wing and Art Gallery, as well as an ingredient in efforts to continuously improve the Occupational Health and Safety Management System.

2) For the author of this research as a source of knowledge and knowledge to add insight and professionalism to K3

\section{Materials and Methods}

The methods used for this research are qualitative and quantitative. To find out the description of the implementation of SMK3, a qualitative descriptive method was used. In simple terms, qualitative research is researching informants as research subjects, while descriptive qualitative means descriptive qualitative research which means an in-depth description of the situation or process being studied. Quantitative is to provide performance appraisal criteria in the form of numbers (Moleong, 2002). Collecting information in the form of secondary data such as; the results of interviews, pictures, photos, and direct observations to the construction project. With this data, the implementation of SMK3 will also be obtained on the project. The next step is to determine the interview technique used, namely the structured interview technique in this study, namely:

1) This study uses PP No. 50 of 2012 as a reference to evaluate the value of implementing SMK3

2) Make an interview checklist containing 12 criteria with 166 advanced criteria elements

In this study, the SMK3 assessment was carried out using an interview checklist based on the Government Regulation of the Republic of Indonesia No. 50 of 2012. With 12 criteria containing 166 criteria elements.

The checklist is addressed to Project Manager respondents, Construction K3 Experts, K3 Officers, Structural Implementers, and MEP implementers by considering that the interviewee understands about SMK3 (Occupational Health and Safety Management System). ) in the Ayana North Wing Bali Building Construction Project. After obtaining the total score from the respondents, then the final results are searched in the following way.

$$
\text { Success }=\frac{\sum \text { Fulfillment value }}{166 \text { Criterias }} \times 100 \%
$$

To get an assessment of the level of implementation of SMK3, it is done by weighing the scale based on PP No. 50 of 2012:

1) For the level of achievement of the implementation of $0-59 \%$ including the level of assessment of implementation is less.

2) For the level of achievement of the implementation of 60-84\% including the level of assessment of good implementation.

3) For the level of achievement of the implementation of $85-100 \%$ including the level of assessment of satisfactory implementation.

\section{Results and Discussions}

\section{Respondent profile}

Sutapa, I. K., Yuni, N. K. S. E., Susila, I. N. D., Wibawa, . I. G. S., \& Santiana, I. M. A. (2022). Evaluation of the implementation of occupational safety and health management systems on the ayana nort wing bali construction project. International Research Journal of Engineering, IT \& Scientific Research, 8(1), 1-6. https://doi.org/10.21744/irjeis.v8n1.2034 
Interview respondents in this study were directly related to staff in charge of implementing SMK3 who have a high position/coordinator and staff who understand SMK3 and have experience in the field of K3 at the Ayana Nort Wing Building Project and Art Gallery Jln Karang Mas Jimbaran, Kec. South Kuta, Kab. Badung Bali. As follows:

Table 1

Respondent

\begin{tabular}{lll}
\hline Position/Position on the Project & Experience & Amount \\
\hline Project Manager & 20 years & 1 person \\
Construction K3 Expert & 7 years & 1 person \\
K3 Officer & 4 years & 1 person \\
Structural Executor & 10 years & 1 person \\
Implementing MEP & 9 years & 1 person \\
\hline
\end{tabular}

The checklist that has been prepared will then be used in a structured interview in the form of a question and answer session with the selected respondent, namely the K3 emergency response coordinator in the interview, what is sought in the project, namely, facts and information that occurs in the field to determine the level of evaluation of the implementation of SMK3 in building projects Ayana North Wing.

\section{Data collection}

Table 2

Recap interview results

\begin{tabular}{lcc}
\hline \multirow{2}{*}{ Respondent } & \multicolumn{2}{c}{ Implemented Criteria } \\
\cline { 2 - 3 } & Yes & No \\
\hline Project Manager & 152 & 14 \\
Construction K3 Expert & 152 & 14 \\
K3 Officer & 152 & 14 \\
Structural Executor & 152 & 14 \\
Implementing MEP & 143 & 23 \\
\hline
\end{tabular}

That from 12 criteria from 166 elements for PP No. 50 the Year 2012 for the advanced category, 152 criteria have been implemented and 14 have not been implemented from respondents in the Ayana North Wing Bali building construction project. Recapitulation based on respondents' answers (checklist) analysis using the assessment method based on the Rule of Law no. 50 of 2012. And the results of the development of the Occupational Health and Safety Management System (SMK3) in the Ayana North Wing Bali building construction project.

Table 3

Recapitulation of criteria based on respondents' answers

\begin{tabular}{|c|c|}
\hline Respondent & Advanced Level \\
\hline Project Manager & 1157 \\
\hline Construction K3 Expert & 157 \\
\hline K3 Officer & 157 \\
\hline Structural Executor & 157 \\
\hline Implementing MEP & 143 \\
\hline \multicolumn{2}{|l|}{$\sum$ Total Rank } \\
\hline \multicolumn{2}{|l|}{ Rata-rata : } \\
\hline$\sum$ Total Rank & \multirow{2}{*}{154.2} \\
\hline 5 & \\
\hline
\end{tabular}


Based on the table above, it can be concluded that the average value of the respondents obtained the number 154.2 for the development of SMK3 in the Ayana North Wing Bali building construction project in Jimbaran. Next, categorize the average value of the levels by using the formula applied to Law No. 50 of 2012, as follows:

$$
\begin{aligned}
& \text { Succes }=\frac{\sum \text { Fulfilment value }}{166 \text { Criterias }} \times 100 \% \\
& \text { Succes }=\frac{154.2}{166} \times 100 \% \\
& \text { Succes }=92.89 \%
\end{aligned}
$$

It can be seen that the results of the success score reached $92.89 \%$ based on 12 criteria from 166 criteria elements that were included in the advanced level category and were in the satisfactory category and from the table above it can be concluded that the level of evaluation of the implementation of the Occupational Health and Safety Management System (SMK3) in the Ayana North building construction project Bali is a very satisfactory level of implementation for the project and Occupational Safety and Health for workers has provided a sense of security.

\section{Conclusion}

Based on the results of the SMK3 Implementation Evaluation conducted, it can be concluded that:

a) For this study, the application of SMK3 for the Ayana North Wing building uses Reference PP No. 50 of 2012 as an evaluation material with 12 criteria containing 166 criteria elements.

b) The application of SMK3 (Occupational Safety and Health Management System) for the construction of the Ayana Nort Wing Building has been satisfactory from the 12 criteria in the percentage obtained $92.89 \%$ belonging to the category $85-100 \%$ the level of research application is satisfactory and provides a sense of security

Conflict of interest statement

The authors declared that they have no competing interests.

Statement of authorship

The authors have a responsibility for the conception and design of the study. The authors have approved the final article.

Acknowledgments

We are grateful to two anonymous reviewers for their valuable comments on the earlier version of this paper.

Sutapa, I. K., Yuni, N. K. S. E., Susila, I. N. D., Wibawa, . I. G. S., \& Santiana, I. M. A. (2022). Evaluation of the implementation of occupational safety and health management systems on the ayana nort wing bali construction project. International Research Journal of Engineering, IT \& Scientific Research, 8(1), 1-6. https://doi.org/10.21744/irjeis.v8n1.2034 


\section{References}

Apsari, A. E., \& Purnomo, H. (2020). An Occupational safety and health (OSH) factors identified in Indonesian batik textile small/medium enterprises. International Research Journal of Engineering, IT \& Scientific Research, 6(2), 55-64. https://doi.org/10.21744/irjeis.v6n2.877

Bergado, D. T., Long, P. V., \& Murthy, B. S. (2002). A case study of geotextile-reinforced embankment on soft ground. Geotextiles and Geomembranes, 20(6), 343-365. https://doi.org/10.1016/S0266-1144(02)00032-8

Darwis, A. M., Nai'em, M. F., Thamrin, Y., Rahmadani, S., \& Amin, F. (2021). Safety risk assessment in construction projects at Hasanuddin University. Gaceta Sanitaria, 35, S385-S387. https://doi.org/10.1016/j.gaceta.2021.10.057

Endroyo, B., Yuwono, B. E., \& Mardapi, D. (2015). Model of learning/training of Occupational Safety \& Health $(\mathrm{OSH})$ based on industry in the construction industry. Procedia Engineering, 125, 83-88. https://doi.org/10.1016/j.proeng.2015.11.013

Fernández-Muñiz, B., Montes-Peón, J. M., \& Vázquez-Ordás, C. J. (2009). Relation between occupational safety management and firm performance. Safety science, 47(7), 980-991. https://doi.org/10.1016/j.ssci.2008.10.022

Herdiansyah, H. (2015). Wawancara, Observasi, dan Focus Groups Sebagai. Instrumen Penggalian Data Kualitatif, PT. Rajadrafindo Persada, Depok.

Lee, C. Y., Hull, T. S., \& Poulos, H. G. (1995). Simplified pile-slope stability analysis. Computers and Geotechnics, 17(1), 1-16. https://doi.org/10.1016/0266-352X(95)91300-S

Leyn, S. P. W. C. B. (2019). Evaluasi Penerapan Keselamatan Dan Kesehatan Kerja (K3)(Studi Kasus di PT. Indokon Raya) (Doctoral dissertation, UNIVERSITAS 17 AGUSTUS 1945).

Malkawi, A. I. H., Hassan, W. F., \& Abdulla, F. A. (2000). Uncertainty and reliability analysis applied to slope stability. Structural safety, 22(2), 161-187. https://doi.org/10.1016/S0167-4730(00)00006-0

Moleong, L. J. (2002). Metodologi Penelitian Kualitatif, cetakan ketujuh belas. Penerbit PT Remaja Rosdakarya, Bandung.

Noorzad, R., \& Mirmoradi, S. H. (2010). Laboratory evaluation of the behavior of a geotextile reinforced clay. Geotextiles and Geomembranes, 28(4), 386-392. https://doi.org/10.1016/j.geotexmem.2009.12.002

Santoso, G. (2004). Manajemen keselamatan dan kesehatan kerja. Prestasi Pustaka Publisher.

Sholihah, Q. (2018). Keselamatan dan Kesehatan Kerja Konstruksi. Universitas Brawijaya Press.

Sousa, V., Almeida, N. M., \& Dias, L. A. (2014). Risk-based management of occupational safety and health in the construction industry-Part 1: Background knowledge. Safety science, 66, 75-86. https://doi.org/10.1016/j.ssci.2014.02.008

Tao, Z., Shu, Y., Yang, X., Peng, Y., Chen, Q., \& Zhang, H. (2020). Physical model test study on shear strength characteristics of slope sliding surface in Nanfen open-pit mine. International Journal of Mining Science and Technology, 30(3), 421-429. https://doi.org/10.1016/j.ijmst.2020.05.006

Xie, J., Uchimura, T., Wang, G., Selvarajah, H., Maqsood, Z., Shen, Q., ... \& Qiao, S. (2020). Predicting the sliding behavior of rotational landslides based on the tilting measurement of the slope surface. Engineering Geology, 269, 105554. https://doi.org/10.1016/j.enggeo.2020.105554

Zambrano, T. Y. M., Zambrano, M. G. R., \& Plaza, C. L. M. (2021). Loom \& barter in the production and trade of hammocks and saddlebags: an ancestral approach. International Research Journal of Engineering, IT \& Scientific Research, 7(5), 176-184. https://doi.org/10.21744/irjeis.v7n5.1901 